\title{
Н.С. Хрущёв и борьба с излишествами в советской архитектуре (1949-1954 годы)
}

\author{
С.О.Кузнецов, Комитет по архитектуре и градостроительству города Москвы, Москва
}

В статье на основе архивных материалов показано, что градостроительная повестка Н.С. Хрущёва, ориентированная на «борьбу с излишествами» в советской архитектуре, сформировалась задолго до 1954 года. Фактически ещё в тридцатые годы он высказывался за экономию при строительстве в Москве. После возвращения на пост первого секретаря Московского комитета Коммунистической партии в декабре 1949 года Н.С. Хрущёв попытался изменить парадигму градостроительной политики: во время его деятельности в Москве был пересмотрен амбициозный план реконструкции центра, разработанный при его предшественнике Г.М. Попове. Хрущёв поддержал мероприятия по типизации, стандартизации и индустриализации строительства; предложил реформу строительной отрасли Москвы, снизил долю ведомственного строительства, которое вело к распылению усилий; перенёс фокус внимания с магистралей на окраинные кварталы. Целями его политики были экономия государственных ресурсов и развитие массового жилищного строительства. Можно предположить, что известное постановление ЦК КПСС и СМ СССР от 4 ноября 1955 года № 1871 «0б устранении излишеств в проектировании и строительстве» в значительной степени опиралось на результаты деятельности Хрущёва в области градостроительства в Москве после Великой Отечественной войны.

Ключевые слова: Генеральный план реконструкции г. Москвы 1951-1960 годов, борьба с излишествами в архитектуре, советская архитектура, Н.С. Хрущёв, И.В. Сталин.

\section{N.S. Khrushchev and the Struggle Against Excesses in Soviet Architecture (1949-1954)}

S.0. Kuznetsov, Committee for Architecture and Urban Planning of Moscow, Moscow

According to traditional historiography, the "struggle against excesses" in Soviet architecture began unexpectedly, without visible prerequisites, in 1954. Based on a study of archival materials, this article argues that Khrushchev began reshaping the construction industry of Moscow almost immediately after being appointed First Secretary of the city's Party Committee at the end of 1949. His reforms involved policies of typization, standardization and industrialization of housing construction. As a result, the well-known November 4, 1955 TsK decree "On the elimination of excesses in design and construction" was not as spontaneous as has been thought, but was the outcome of a long and complex process of change in Soviet architecture and city planning.
Keywords: General Plan for the reconstruction of Moscow 1951-1960, the fight against excesses in architecture, soviet architecture, N.S. Khrushchev, I.V. Stalin

В архитектуроведческой литературе существует мнение, что борьба с излишествами в архитектуре началась неожиданно. Так, Г.И. Ревзин указывает, что архитектурная реформа была запущена в 1954 году после обращения в ЦК КПСС Георгия Градова «о вредительстве старых профессоров», которые не дают перейти на новые индустриальные методы строительства и тем самым препятствуют удовлетворению потребности народа в жилье [1]. Некоторые исследователи считают, что новый партийный лидер страны Н.С. Хрущёв поставил архитекторов «перед пропастью», «катастрофическим образом» поменяв архитектурный стиль в 1954 году [2]. Вот как описывает этот исторический момент очевидец событий С.0. Хан-Магомедов: «И вот в одночасье всё рухнуло. Были письма в ЦК КПСС (1954 г.) группы мало известных в то время архитекторов (Г. Градов, Н. Щетинин, Прозоровский, Пожарский), которые критиковали творческую направленность советской архитектуры, оценивая её как эклектическую стилизацию... Все рассматривали эти письма как незначительный инцидент. И для подавляющего большинства советских архитекторов было полной неожиданностью, что руководство страны выступило на стороне авторов этих писем. Как гром с ясного неба прозвучала тогда для нас речь Хрущёва на совещании строителей 7 декабря 1954 г.» [3]. Вопреки этому устоявшемуся мнению, 0.В. Казаковой в своей статье удалось собрать довольно много данных, доказывающих, что если не борьба, то по крайней мере критика чрезмерного, неоправданного украшательства присутствовала и в тридцатые годы как в профессиональной прессе, так и в некоторых правительственных постановлениях; после Великой Отечественной войны она проявилась в попытках внедрения стандартизации, индустриализации и применения типовых проектов в строительстве жилых, административных и промышленных зданий в Москве [4].

После Великой Отечественной войны в Москве существенно изменились градостроительные условия: численность населения достигла пяти миллионов, далеко превысив запланированную; предусмотренное в 1935 году увеличение территории города до 60 тыс. га оказалось недостаточным. Это стало одним из обстоятельств, которые привели к решению о разработке нового плана реконструкции столицы, рассчитанного на 20-25 лет ${ }^{1}$.

Послевоенное десятилетие характерно расцветом «триумфального» направления в архитектуре и стремлением к 
гигантомании при проектировании городских центров [5; 6]. Подготовленные в 1949 - начале 1950 года планы реконструкции центра Москвы стали проявлением этой тенденции². Так, например, предполагалось создание огромной центральной площади на месте ГУМа, Гостиного двора и Исторического музея, обрамлённой монументальными общественными постройками, трибунами и триумфальной аркой, расчистка Китай-города и Зарядья. Здание Политехнического музея также запланировали к сносу, чтобы объединить площади Новую, Старую и Дзержинского, широкий проезд служил их продолжением и связывал с площадью Свердлова. Манежную площадь предполагалось расширить за счёт сноса Манежа и использования части Александровского сада, украсить зелёными партерами, фонтанами и монументами. Все эти обширные общественные пространства должны были фланкироваться монументальными зданиями министерств и учреждений, имеющих целостное ансамблевое решение. В результате размер застроенных кварталов центра уменьшался со 179 до 118 га, а территория площадей, скверов и проездов увеличивалась со 106 до 167 га. Столь впечатляющий план требовал выселения 30 тыс. человек и сноса 4,5 млн кв. метров общественной и жилой площади. Тотальный снос для разбивки парка ожидал Берсеневскую, Софийскую и Раушскую набережные, расположенные на них станции Мосэнерго и фабрику «Красный Октябрь»³. В Замоскворечье проектировалось полное замыкание Бульварного кольца на участке от Устьинского моста до Кропоткинских ворот новым бульваром шириной 60 м, расширение улицы Большой Ордынки до 100-120 м и застройка всего пространства от набережных до проектируемого бульвара многоэтажными домами. Эти планы поддерживал Г.М. Попов, после войны бывший единоличным руководителем в исполнительной и партийной ветвях власти в городе, совмещая должности первого секретаря Московского комитета ВКП(б) и председателя Исполкома Моссовета (рис. 1).

Указания Сталина архитекторам были противоречивыми. С одной стороны, он требовал создавать «памятники эпохи, чтобы будущие поколения чувствовали в каждом построенном доме, в каждом построенном здании дыхание эпохи коммунизма» [7, с. 74]. Самыми яркими их образцами, как известно, стали сталинские высотки. С другой стороны, комментируя готовящийся генеральный план, вождь раскритиковал проектирование «пустых» зданий - дворцов, клубов, гимнастических залов, домов пионеров, и рекомендовал «напереть» на строительство жилья, больниц и школ 4 . По пожеланию Сталина было принято новое решение Политбюро ЦК ВКП(б) о составлении плана не на 25, а на десять лет ${ }^{5}$. Не дожидаясь переработки плана реконструкции, 3 октября 1949 года Совет министров СССР принял постановление об ускорении жилищного строительства в Москве. 0но обязывало построить за десять лет 10 млн кв. метров жилой площади, 470 школ, больницы на 26 тыс. коек, дороги и набережные, благоустроить въезды в город по железной дороге. Последнее было внесено по желанию Сталина ${ }^{6}$. Против московского лидера Г.М. Попова, допустившего

\footnotetext{
${ }^{1}$ Постановление СМ СССР и ЦК ВКП(б) «0 разработке нового генерального плана реконструкции Москвы» от 01.02.1949. / Косенкова Ю.Л., Волчок Ю.П. Хроника архитектурно-градостроительного процесса в СССР послевоенного периода (1945-1955). 1949 год. - Режим доступа: www.niitiag.ru/file/594 (дата обращения: 07.07.2019).

${ }^{2}$ Напр., ЦГА г. Москвы. Ф. Т-41. Оп. 1. Д. 209. Проект реконструкции центра Москвы и создания нового проспекта от центра до Ленинских гор. 1949 г. Архитектурно-планировочные мастерские № 1 (и.о. руководителя Назаров), № 2 (и.о. руководителя Кривоносов), № 3 ( и.о. руководителя Уллас); Д. 248. Форпроект реконструкции центра гор. Москвы (район Замосковречья в пределах Бульварного кольца). 1950 г. Мастерская № 3 Государственных архитектурных мастерских. Авторы проекта Н.Я. Колли, В.В. Калинин, В.П. Сергеев.

${ }^{3}$ ЦГА г. Москвы. Ф. Т-41. Оп. 1. Д. 209. Л. 1-12. Пояснительная записка к проекту реконструкции центра Москвы. 1949 г.

${ }^{4}$ ЦГА Москвы. Ф. П-3. Оп. 119. Д. 109. Л. 54-57. Замечания И.В. Сталина при обсуждении вопроса о Генеральном плане реконструкции Москвы на заседании Политбюро ЦК ВКП(б) 17 июня 1949 г.

${ }^{5}$ РГАСПИ. Ф. 17. Оп. З. Д. 1076. Л. 2. Протокол ПБ № 69 от 17.06 .1949$.
}

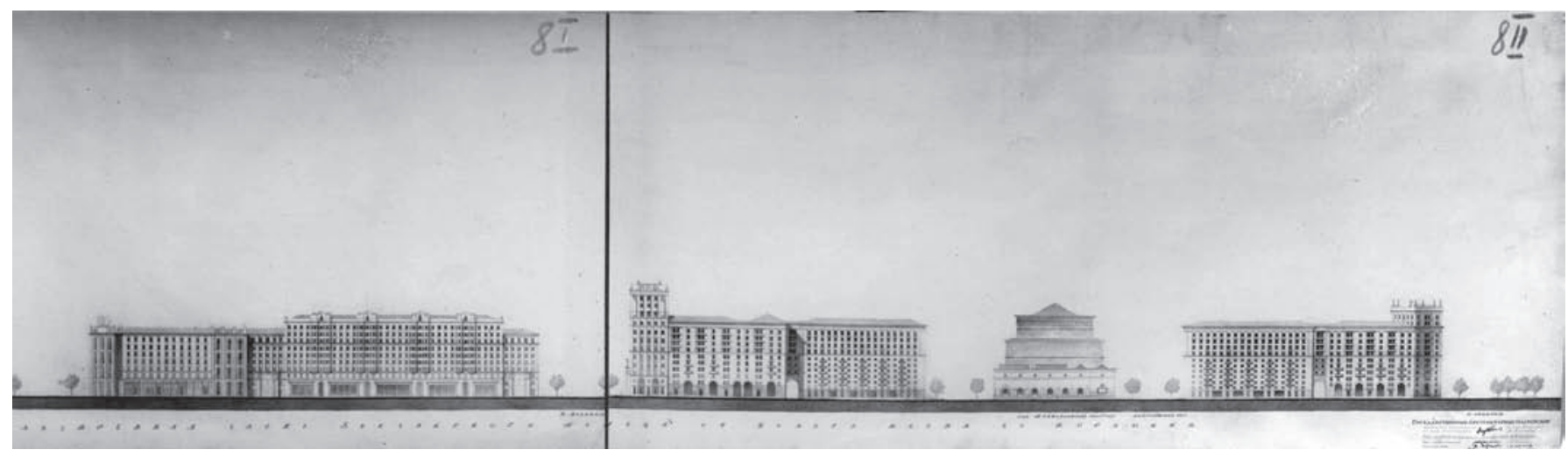

Рис. 1. Проект реконструкции центра в районе Замоскворечья. Фрагмент развёртки фасадов Бульварного кольца от Нового моста до улицы Полянки (источник: ЦГА г. Москвы. Ф. T-41. On. 1. Д. 248) 
ряд политических промахов, началась кампания, в результате которой он был уволен со всех должностей. В декабре 1949 года из Киева заменить Попова был срочно вызван секретарь ЦК КПСС Н.С. Хрущёв, к этому времени превратившийся в одного из сталинских любимцев. Хрущёв был одним из первых, кто ещё в тридцатые годы заговорил о необходимости индустриализации строительства: в 1935 году, будучи секретарём московского комитета партии, на совещании по вопросам строительства он призвал «изготовлять строительные детали заводским путём и за счёт этого неизмеримо шагнуть вперёд как в отношении темпов, так и в отношении резкого снижения стоимости строительства». Эту же мысль Хрущёв повторил через десять лет, выступая с речью о восстановлении городов [4, с. 40, 42].

К теме повышения скорости и экономичности строительства новый лидер Москвы вернулся вновь в начале 1950 года. К марту им были подготовлены для Сталина замечания на проект «Постановления о плане реконструкции Москвы на 1950-1959 гг.», выполненный Административной комиссией Исполкома Моссовета при Г.М. Попове. В них приводились данные о строительстве в Москве: в 1949 году было введено в строй 405,7 тыс. кв. метров жилья, из них 258 тыс. - в однодвух- трёхэтажных домах барачного типа на окраинах города (рис. 2, 3). На главных магистралях и набережных в 1949 году шло строительство 114 многоэтажных домов. При установ-

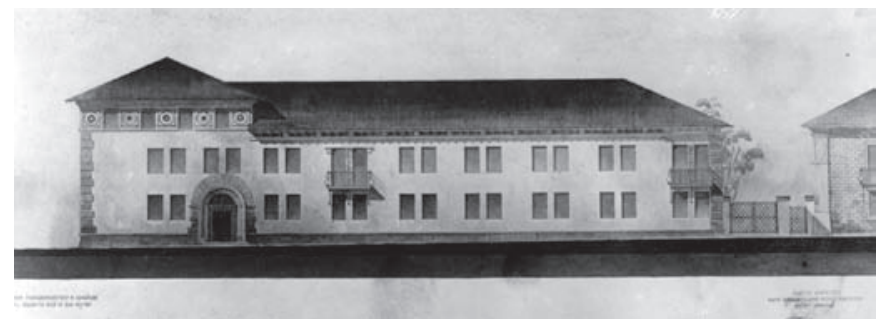

Рис. 2. Жилые дома Министерства цветной металлургии в Измайлове. Фасад по проезду № 993. Архитектор Я.А. Аир-Бабамян. 1947 год (источник: ГнИМА им. А.В. Щусева. Коллекция Т.Б. Негатив 171/9)

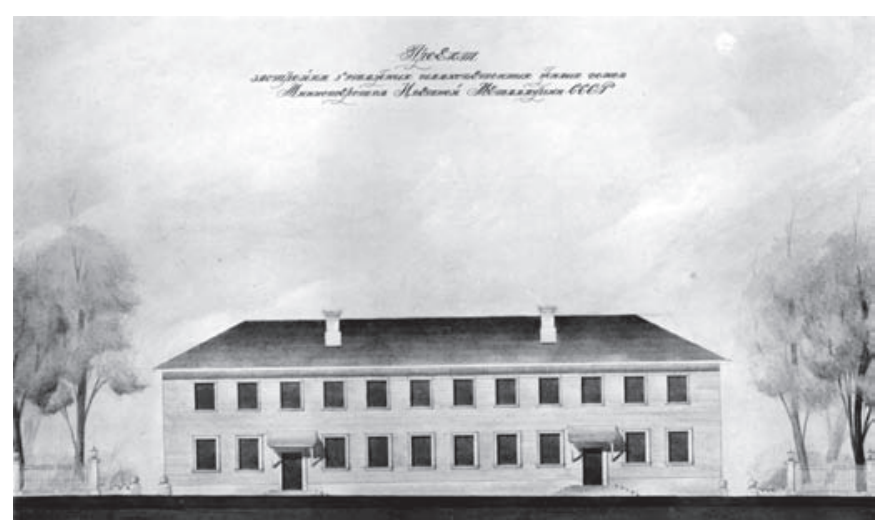

Рис. 3. Ведомственное строительство. Жилой посёлок Главвоенпромстроя в Измайлове. Общежитие № 23 на 169 человек. Архитектор Г.М. Мельчук. 1947 год. (источник: ГНИМА им. А.В. Щусева. Коллекция ХІ. Негатив 4606. Собр. музея архитектуры P-I а 2657/3) ленных планах в 10 млн кв. метров это было недопустимо мало. В 1949 году у министерств и ведомств в Москве было 60 строительных контор с с общей численностью рабочих различных специальностей - 130 тыс. человек. При этом строительство жилья составляло только 30 процентов от их заказов. Доля Моссовета в строительстве жилья упала по сравнению с ведомственной и составила около 15\%. Трест «Мосгорпроект» был маломощной организацией. Если до войны в проектных мастерских Мосгорисполкома работало 1200 человек, то в 1949 году - всего 500. Этих ресурсов было недостаточно для выполнения программы строительства. Хрущёв предложил изменить структуру проектирования и строительства, повысить участие Моссовета в строительстве до 25\%; создать при Моссовете Главное управление по строительству жилых и гражданских зданий во главе с заместителем председателя Исполкома, которое должно планировать и координировать всё жилищное строительство как городское, так и ведомственное. В качестве составляющих процесса реорганизации были выделены индустриализация строительства, развитие производства типовых конструкций и строительных материалов. Хрущёв считал, что нужно по-новому организовать проектно-строительный процесс. С этой целью создать Управление по реконструкции города, возложить на него задачи не только проектирования, но и руководства жилищным и гражданским строительством, контроль за выполнением планов ведомств, перспективное и текущее проектирование больниц и школ, научное обобщение градостроительного опыта; для реализации этих задач - создать проектный институт, усилить секцию типового проектирования домов; передать Управлению функцию отвода земельных участков ${ }^{7}$.

Некоторые предложения Хрущёва были выполнены уже в 1951 году. В июне были образованы Отдел жилищного и гражданского строительства Мосгорисполкома и Архитектурнопланировочное управление. Его начальником остался А.В Власов, в 1950 году назначенный главным архитектором Москвы. В мае 1951-го были созданы Проектный институт «Моспроект» (в июне переименован в Институт проектирования жилищногражданского строительства в г. Москве - «Моспроект» АПУ Мосгорисполкома) и Научно-исследовательский и проектный институт Генплана Москвы ${ }^{8}$.

В 1950-1951 годы, наряду с реформированием органов управления архитектурно-градостроительной деятельностью, начинает меняться подход к проектированию и строительству. Было создано САКБ (Специальное архитектурно-конструкторское бюро) типового проектирования при Моспроекте. В январе 1952 года была утверждена общесоюзная Инструкция по составлению проектов и смет по промышленному и жилищно-гражданскому строительству, которая предписывала не

${ }^{6}$ ЦГА Москвы. Ф. П-3. 0п. 119. Д. 109. Л. 54-57.

${ }^{7}$ ЦГА г. Москвы. Ф. П-4. 0п. 45. Д. 19. Л. 9-15, 38, 50-53.

8 Постановления Совета Министров СССР от 06.04.1951 № 1137 «0б укрупнении проектных организаций и ликвидации мелких проектных контор»; от 2.06.1951 № 1873 «0б организации Архитектурно-планировочного управления города Москвы» [10, с. 482, 736]. 
допускать излишеств при проектировании, избегать излишних архитектурных требований и необоснованных объёмов гражданских зданий, максимально использовать типовые проекты 9

Буквально через неделю, 2 февраля 1952 года, было принято постановление об утверждении нового генерального плана Москвы на 1951-1960 годы. Его приоритетами были объявлены быстрое увеличение объёмов жилищного строительства, использование типовых конструкций и индустриальных методов строительства, благоустройство города, развитие топливноэнергетического хозяйства, водоснабжения и канализации, транспорта и связи [8]. По предложению Сталина в постановление внесли пункт о повышении этажности домов до 10-12-14 этажей ${ }^{10}$. В профессиональных журналах стало расти число публикаций на темы техники строительства, скоростных методов возведения домов, применения сборных заводских конструкций. В статье, посвящённой принятию генерального плана, главный архитектор Москвы Власов подчеркнул, что «советское зодчество включает в себя не только мастерство художника-композитора, но также искусство конструктора, опыт строителя и экономиста... Совершенно очевидно, что только полный синтез искусства и техники может обеспечить дальнейшее развитие социалистической архитектуры» [9, с. 3].

Под руководством Н.С. Хрущёва московские власти сконцентрировались на решении жилищной проблемы. За пятилетку 1951-1955 годов план жилищного строительства в Москве впервые был перевыполнен: построено 4305 тыс. кв. метров. Близко к выполнению плана было количество введённых в эксплуатацию больниц и школ. Большая часть жилых домов была возведена на второстепенных улицах, а не на главных магистралях (2450 тыс. кв. метров или около 60 процентов). Если раньше на окраинах велось ведомственное барачное строительство, противостоять

\footnotetext{
${ }^{9}$ Инструкция по составлению проектов и смет по промышленному и жилищно-гражданскому строительству [Электронный ресурс] / Утв. Постановлением См СССР от 26 января 1952 г. № 486. - Режим доступа: www. libussr.ru (дата обращения: 28.06.2019).

${ }^{10}$ ЦГА Москвы. Ф. П-3. Оп. 119. Д. 109. Л. 55.
}

которому московскому руководству не удавалось, то с 1951 года переход на окраины стал осознанным решением. Преобладающее строительство в периферийных районах, во дворах и на второстепенных улицах объяснялось тем, что для него не требовался большой снос существующих зданий, выселение жильцов и создание «манёвренного фонда», предназначенного для временного переселения. Это сильно снижало затраты на предоставление новых квартир. Образцовой была признана застройка кварталов Измайлова, Хорошёвского шоссе и Песчаных улиц. Они были одними из первых районов качественного массового жилищного строительства на бывших окраинах. Информация о применявшихся там передовых индустриальных методах строительства и использовании типовых архитектурных деталей постоянно появлялась в прессе (рис. 4, 5, 6).

Хотя по желанию Сталина для центральных улиц проектировались здания повышенной этажности, Хрущёв наиболее экономичными считал дома без лифтов, в четыре-шесть этажей.

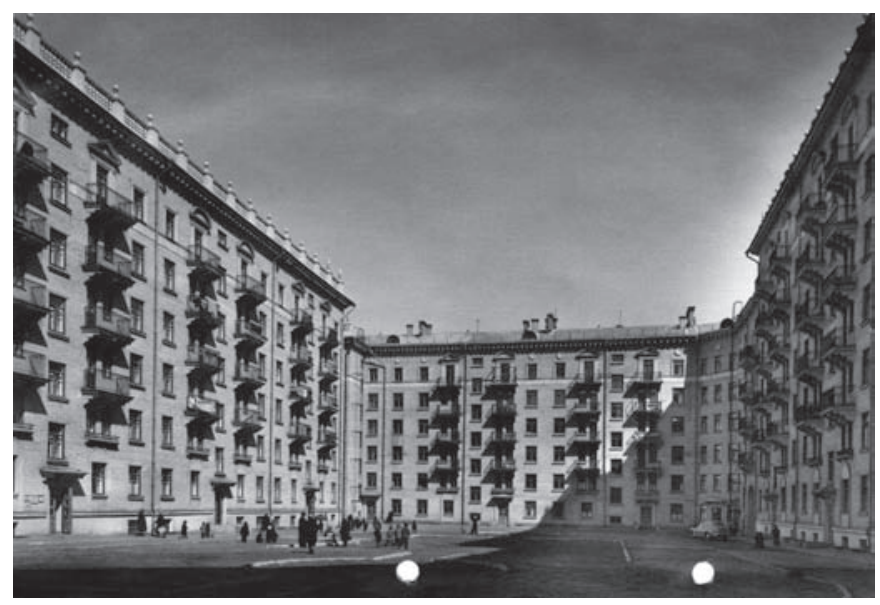

Рис. 4. Жилые дома на Песчаной уличе. Вид дворовых фасадов. Архитектор 3.М. Розенфельд, Швец, Болонов, Зильбеглейд. 1950 год. Фото А.А. Сорокина (источник: ГНИМА им. А.В. Щусева. Коллекция XI. Негатив 9775)

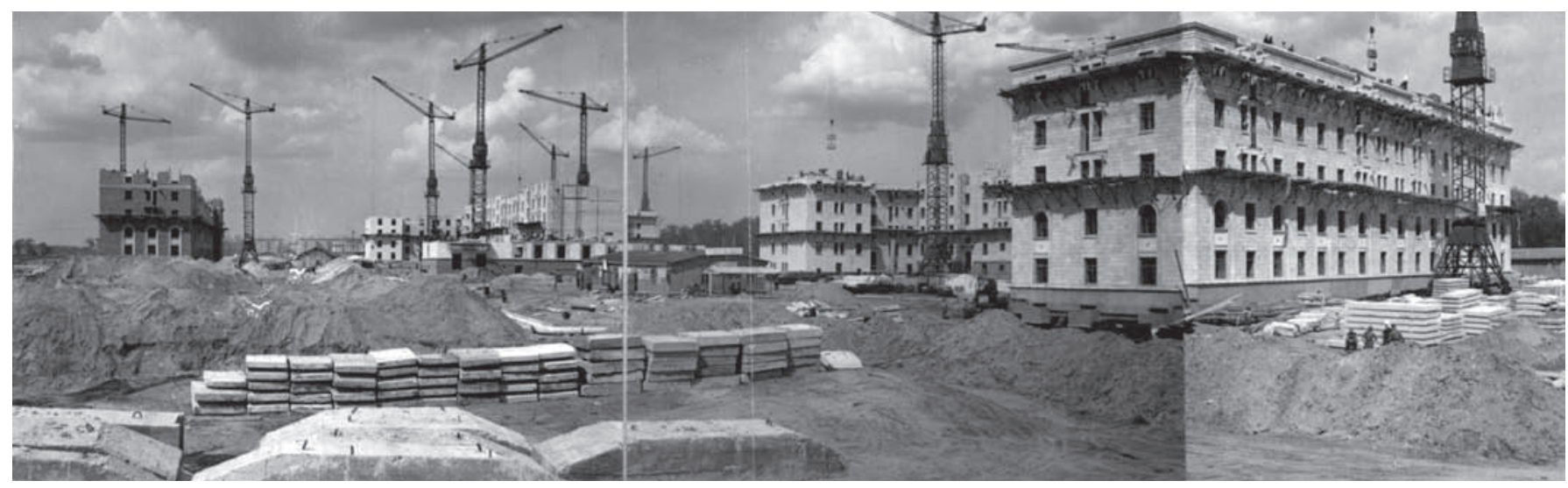

Pис. 5. Новопесчаные улицы. Строительство жилых домов в шестом квартале. Июнь, 1954 года. Фото А. Тартаковского (источник: ГнИМА им. А.В. Щусева. Коллекция XI. Негатив 14056/1-3) 
Их доля в застройке в пятидесятые годы составила почти 60\%, в то время как зданий в 10 этажей и выше - 17,7\% ${ }^{11}$. В 1954 году было осуществлено ещё одно начинание Хрущёва: строительные организации Москвы были объединены под началом Главного управления по жилищному и гражданскому строительству при Мосгорисполкоме (Главмосстрой). Ему были переданы все строительные предприятия, раньше подчинявшиеся союзным министерствам нефтяной промышленности, угольной промышленности, внутренних дел, путей сообщения, авиационной промышленности и ещё целого ряда ведомств; союзным министерствам, ведавшим строительством. Также в Главмосстрой включили управления Мосгорисполкома: жилищного строительства, Москультстрой, Мосподземстрой, строительства дорог, мостов и трамвайных путей [10, с. 452-453]. Это означало концентрацию всей строительной индустрии Москвы в одних руках, что привело к значительному ускорению ввода нового жилья.

Ситуация в архитектуре стала стремительно меняться после избрания 7 октября 1953 года Н.С. Хрущёва первым секретарём ЦК партии. Фактически полный отказ от сталинского архитектурного стиля стал первым сигналом десталинизации и одной из первых в череде реформ, инициированных новым лидером государства [11]. В 1954 году в профессиональной и периодической печати росло число публикаций с осуждением «штучного проектирования», помпезности, украшательства и эклектизма советской архитектуры 1930-х - 1953 годов. Как когда-то направления авангарда, сталинский ампир был осуждён за формализм и ему вменили буржуазность [2; 15]. 7 декабря 1954 года в Москве состоялось Всесоюзное совещание строителей, архитекторов и работников промышленности строительных материалов, строительного и дорожного машиностроения, проектных и научно-исследовательских организаций, на котором советская архитектурная школа была подвергнута резкой критике. Ещё через год, в ноябре 1955-го, сталинская архитектура была «решительно осуждена» известным постановлением Центрального Комитета КПСС и Совета министров

${ }^{11}$ ЦГА г. Москвы. Ф. Т-41. 0п. 1. Д. 1136. Л. 4-8.

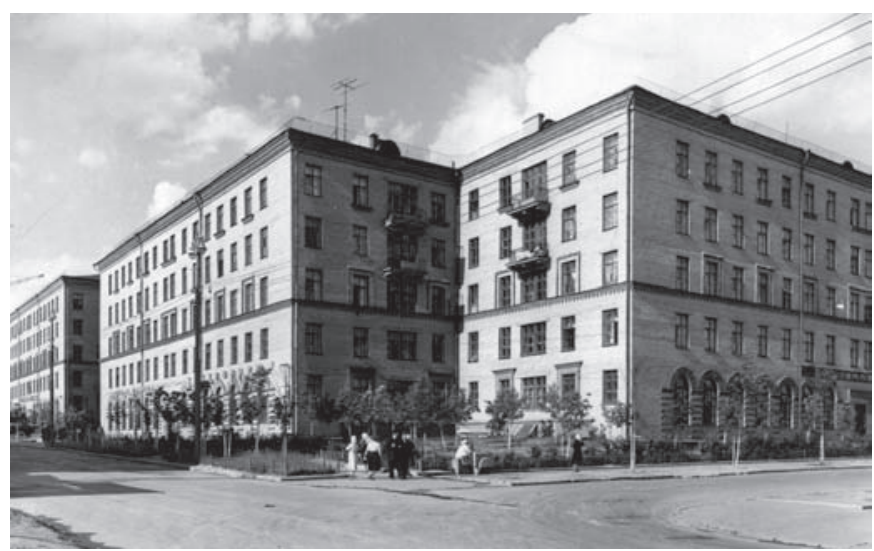

Рис. 6. Измайлово. Жилые дома по Первомайской улице. Перспектива. 1954 год. Фото А.А. Сорокина (источник: ГНИМА им. А.В. Щусева. Коллекция XI. Негатив 16534)
СССР от 4 ноября 1955 года № 1871 «0б устранении излишеств в проектировании и строительстве».

Идеологические основы советской архитектуры до середины 1950-х годов не подвергались пересмотру: ансамблевый принцип, важность монументальной застройки главных магистралей и высокие художественные качества архитектурного образа города не вызывали сомнений. На протяжении всего сталинского периода истории СССР сосуществовали две архитектурно-градостроительные тенденции: «ансамблевого мышления» и монументальной застройки центральных площадей и магистралей городов, призванные отражать величие достижений советской эпохи. Как отмечено Ю.Л. Косенковой, к началу 1950-х годов ансамбль «превратился в некий символ совершенства... заслоняющий собой все остальные аспекты развития города» [5, с. 123-158]. Одновременно постепенно вызревало понимание того, что решение нарастающих социальных проблем возможно только с переходом к новым методам индустриализации и типизации для организации массового жилищного строительства. Понимание этой необходимости росло и в среде архитекторов. Для Москвы его воплощение на практике в большой степени связано с назначением на пост первого секретаря МК ВКП(б) Н.С. Хрущёва. Поэтому можно сделать вывод о том, что хотя для многих архитекторов «стилевая ломка» 1954-1955 годов и стала неожиданностью, она тем не менее явилась закономерным продолжением московского опыта Н.С. Хрущёва начала 1950-х годов в области градостроительства.

\section{Лuтература}

1. Ревзин, Г.И. Интервью «Дорогой наш Никита Сергеевич». Архитектура от Сталина до Хрущёва [Электронный ресурс] Г.И. Ревзин // «Эхо Москвы». Официальный сайт. - Режим доступа: https://echo.msk.ru/programs/hrushev/687897echo/ (дата обращения 04.03.2018).

2. Хмельницкий, Д.С. Конец стиля. К пятидесятилетию гибели сталинской архитектуры [Электронный ресурс] // Д.С. Хмельницкий // Проект Классика. - 2005. - № XIII-MMV. - Peжим доступа: http://www.projectclassica.ru/school/13_2005/ school2004_13_01a.htm (дата обращения 01.03.2018).

3. Хан-Магомедов, С.О. Хрущёвский утилитаризм: плюсы и минусы [Электронный ресурс] // НИИТИАГ. Официальный сайт - Режим доступа: http://www.niitag.ru/info/doc/?89 (дата обращения: 04.03.2019).

4. Казакова, О.В. Борьба с излишествами в 1930-1950-е годы / О.В. Казакова // Архитектура сталинской эпохи: опыт исторического осмысления; сост. и отв. ред. Ю. Л. Косенкова. - Москва : НИИТИАГ РААСН, 2010. - С. 40-48.

5. Косенкова, Ю.Л. Советский город 1940-х - первой половины 1950-х гг. От творческих поисков к практике строительства / Ю.Л. Косенкова. - М. : Эдиториал УРСС, 2000. - С. 123-158.

6. Tarkhanov, A. Kavtaradze C. Stalinist Architecture / A. Tarkhanov. C. Kavtaradze. - New York : Rizzoli, 1992.

7. Таранов, E.В. «Партийный губернатор» Москвы Георгий Попов / Е.В. Таранов. - М. : Издательство Главархива Москвы, 2014. 
8. Бобровников, Н. Неустанно бороться за реализацию генерального плана реконструкции Москвы / Н. Бобровников // Архитектура и строительство Москвы. - 1952. - № 2. - С. 1-2.

9. Власов, А.В. Очередные задачи московских архитекторов / А.В. Власов // Архитектура и строительство Москвы. - 1952. - № 1. - С. 3-5.

10. Гарнюк, С.Д. Московская власть. Советские органы управления. Март 1917 - октябрь 1993 : справочник / С.Д. Гарнюк. - М. : Издательство ГАУ г. Москвы, 2011.

11. Горлов, В.Н. Речь Н.С. Хрущёва на Всесоюзном совещании строителей в декабре 1954 г. как один из первых шагов в направлении десталинизации советского общества [Электронный ресурс] / В.Н. Горлов // Вестник МГОУ. Серия «История и политические науки». - 2018. - № 2. - С. 126-131. - Режим доступа: https://cyberleninka.ru/article/v/ rech-n-s-hruschyova-na-vsesoyuznom-soveschanii-stroiteleyv-dekabre-1954-g-kak-odin-iz-pervyh-shagov-v-napravleniidestalinizatsii (дата обращения 05.03.2018).

12. Хмельницкий, Д.С. Реформы Хрущёва. Что случилось с советской архитектурой в пятидесятые годы? Преддверие «оттепели» или профессионализация казарменного социализма? [Электронный ресурс] / Д.С. Хмельницкий // Гефтер. - 2017. - 17.03. - Режим доступа: http://gefter.ru/ archive/21563 (дата обращения 06.12.2018).

\section{References}

1. Revzin G.I. Interv'yu «Dorogoi nash Nikita Sergeevich». Arkhitektura ot Stalina do Khrushcheva. [Elektronnyi resurs] [Interview "Our dear Nikita Sergeevich." Architecture from Stalin to Khrushchev]. "Ekho Moskvy". Ofitsial'nyi sait [Echo of Moscow. Official site]. URL: https://echo.msk.ru/programs/ hrushev/687897-echo/ (Accessed 04.03.2018).

2. Khmel'nitskii D.S. Konets stilya. K pyatidesyatiletiyu gibeli stalinskoi arkhitektury [Elektronnyi resurs] [The end of the style. On the fiftieth anniversary of the death of Stalinist architecture]. Proekt Klassika [Project Klassika], 2005, no. XIIIMMV. URL: http://www.projectclassica.ru/school/13_2005/ school2004_13_01a.htm (Accessed 01.03.2018).

3. Khan-Magomedov S.0. Khrushchevskii utilitarizm: plyusy i minusy [Text] [Hrushchev utilitarianism: pros and cons] [Elektronnyi resurs] // NIITIAG. Ofitsial'nyi sait [NIITIAG. Official site]. URL: http://www.niitag.ru/info/doc/?8 (Accessed 04.03.2019).

4. Kazakova 0.V. «Bor'ba s izlishestvami» v 1930-1950-e gody ["The fight against excesses" in the 1930-1950s]. In
Yu. L. Kosenkova (ed.) Arkhitektura stalinskoi epokhi: opyt istoricheskogo osmysleniya [The architecture of the Stalin era: the experience of historical understanding]. Moscow, NIITIAG RAASN Publ., 2010, pp. 40-48.

5. Kosenkova Yu.L. Sovetskii gorod 1940-kh - pervoi poloviny 1950kh gg. Ottvorcheskikh poiskov k praktike stroitel'stva [Soviet city of the 1940 s - first half of the 1950s From creative searches to construction practice]. Moscow, Editorial URSS Publ, 2000, pp. 123-158.

6. Tarkhanov A., Kavtaradze C. Stalinist Architecture. New York, Rizzoli Publ, 1992.

7. Taranov E.V. «Partiinyi gubernator» Moskvy Georgii Popov ["Party Governor" of Moscow Georgy Popov]. Moscow, Publishing house Glavarkhiva, 2014.

8. Bobrovnikov N. Neustanno borot'sya za realizatsiyu general'nogo plana rekonstruktsii Moskvy [Relentlessly fight for the implementation of the general plan for the reconstruction of Moscow]. Arkhitektura i stroitel'stvo Moskvy [Architecture and construction of Moscow], 1952, no. 2, pp. 1-2.

9. Vlasov A.V. Ocherednye zadachi moskovskikh arkhitektorov [The immediate tasks of Moscow architects]. Arkhitektura $i$ stroitel'stvo Moskvy [Architecture and construction of Moscow], 1952, no. 1, pp. 3-5.

10. Garnyuk S.D. Moskovskaya vlast'. Sovetskie organy upravleniya. Mart 1917 - oktyabr' 1993: spravochnik [Moscow power. Soviet authorities. March 1917 - October 1993: Handbook]. Moscow, GAU g. Moskvy Publ., 2011.

11. Gorlov V.N. Rech' N.S. Khrushcheva na Vsesoyuznom soveshchanii stroitelei v dekabre $1954 \mathrm{~g}$. kak odin iz pervykh shagov v napravlenii destalinizatsii sovetskogo obshchestva [Elektronnyi resurs] [Speech N.S. Khrushchev at the All-Union Conference of Builders in December 1954 as one of the first steps towards the de-Stalinization of Soviet society]. Vestnik MGOU. Seriya «Istoriya i politicheskie nauki» [Bulletin of MGOU. Series "History and Political Science"], 2018, no. 2, pp. 126-131. URL: https://cyberleninka.ru/article/v/rech-n-s-hruschyovana-vsesoyuznom-soveschanii-stroiteley-v-dekabre-1954-g-kakodin-iz-pervyh-shagov-v-napravlenii-destalinizatsii (Accessed 05.03.2018).

12. Khmel'nitskii D.S. Reformy Khrushcheva. Chto sluchilos' s sovetskoi arkhitekturoi v pyatidesyatye gody? Preddverie «ottepeli» ili professionalizatsiya kazarmennogo sotsializma? [Elektronnyi resurs] [Reforms of Khrushchev. What happened to the Soviet architecture in the fifties? The threshold of "thaw" or the professionalization of barracks socialism?]. Gefter, 2017/17/03. URL: http://gefter.ru/archive/21563 (Accessed 06.12.2018).

Сергей Олегович Кузнецов (Москва). Главный архитектор города Москвы, первый заместитель председателя Комитета по архитектуре и градостроительству города Москвы (125047, Москва, Триумфальная площадь, 1. Москомархитектура). Эл.почта: KuznetsovS0@mos.ru

Sergey Olegovich Kuznetsov (Moscow). Chief Architect of Moscow, First Deputy Chairman of the Committee for Architecture and Urban Planning of Moscow (1 Triumfalnaya Square, Moscow, 125047. Moskomarkhitektura). E-mail: KuznetsovS0@mos.ru 